ARTICLE

\title{
General heterostructure strategy of photothermal materials for scalable solar-heating hydrogen production without the consumption of artificial energy
}

\author{
Yaguang Li (i) 1,2,3,6凶 , Xianhua Bai ${ }^{1,6}$, Dachao Yuan ${ }^{1,2,6}$, Fengyu Zhang ${ }^{1,4,6}$, Bo Li $^{1}$, Xingyuan San ${ }^{1}$, Baolai Liang ${ }^{1}$, \\ Shufang Wang (1D ${ }^{1 \times}$, Jun Luo (1) ${ }^{1,5 \otimes} \&$ Guangsheng $\mathrm{Fu}^{1}$
}

Solar-heating catalysis has the potential to realize zero artificial energy consumption, which is restricted by the low ambient solar heating temperatures of photothermal materials. Here, we propose the concept of using heterostructures of black photothermal materials (such as $\mathrm{Bi}_{2} \mathrm{Te}_{3}$ ) and infrared insulating materials $(\mathrm{Cu})$ to elevate solar heating temperatures. Consequently, the heterostructure of $\mathrm{Bi}_{2} \mathrm{Te}_{3}$ and $\mathrm{Cu}\left(\mathrm{Bi}_{2} \mathrm{Te}_{3} / \mathrm{Cu}\right)$ increases the 1 sun-heating temperature of $\mathrm{Bi}_{2} \mathrm{Te}_{3}$ from $93^{\circ} \mathrm{C}$ to $317^{\circ} \mathrm{C}$ by achieving the synergy of $89 \%$ solar absorption and $5 \%$ infrared radiation. This strategy is applicable for various black photothermal materials to raise the 1 sun-heating temperatures of $\mathrm{Ti}_{2} \mathrm{O}_{3}, \mathrm{Cu}_{2} \mathrm{Se}$, and $\mathrm{Cu}_{2} \mathrm{~S}$ to $295^{\circ} \mathrm{C}, 271^{\circ} \mathrm{C}$, and $248^{\circ} \mathrm{C}$, respectively. The $\mathrm{Bi}_{2} \mathrm{Te}_{3} / \mathrm{Cu}$-based device is able to heat $\mathrm{CuO}_{x} / \mathrm{ZnO} / \mathrm{Al}_{2} \mathrm{O}_{3}$ nanosheets to $305^{\circ} \mathrm{C}$ under 1 sun irradiation, and this system shows a 1 sun-driven hydrogen production rate of $310 \mathrm{mmol} \mathrm{g}^{-1} \mathrm{~h}^{-1}$ from methanol and water, at least 6 times greater than that of all solar-driven systems to date, with $30.1 \%$ solar-to-hydrogen efficiency and 20 -day operating stability. Furthermore, this system is enlarged to $6 \mathrm{~m}^{2}$ to generate $23.27 \mathrm{~m}^{3} /$ day of hydrogen under outdoor sunlight irradiation in the spring, revealing its potential for industrial manufacture.

\footnotetext{
${ }^{1}$ Hebei Key Lab of Optic-electronic Information and Materials, The College of Physics Science and Technology, Institute of Life Science and Green Development, Hebei University, 071002 Baoding, China. ${ }^{2}$ College of Mechanical and Electrical Engineering, Key Laboratory Intelligent Equipment and New Energy Utilization of Livestock and Poultry Breeding, Hebei Agricultural University, 071001 Baoding, China. ${ }^{3}$ State Key Laboratory of Photovoltaic Materials \& Technology, Yingli Solar, 071051 Baoding, China. ${ }^{4}$ Department of Materials Science and Engineering, China University of Petroleum Beijing, No. 18 Fuxue Rd., 102249 Beijing, China. ${ }^{5}$ Institute for New Energy Materials \& Low-Carbon Technologies and Tianjin Key Lab of Photoelectric Materials \& Devices, School of Materials Science and Engineering, Tianjin University of Technology, 300384 Tianjin, China. ${ }^{6}$ These authors contributed equally: Yaguang Li, Xianhua Bai,

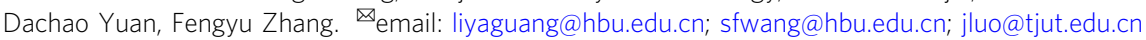


P romoting industrial catalysis consumes a large amount of artificial energy, such as electricity ${ }^{1}$ and fossil-derived energy $^{2}$, which need artificial conversion and input for their final usage. Therefore, constructing artificial-energy-input-free catalysis is the key to human sustainable development. Sunlightdriven catalysis is a typical type of artificial-energy-input-free catalysis that has the potential to solve the energy bottleneck of catalysis $^{3-5}$. At present, sunlight-driven catalysis mainly includes photocatalysis via sunlight-photogenerated carrier-chemical paths and photothermal catalysis via sunlight-hot carrier-chemical paths ${ }^{6,7}$, exhibiting great potential in many fields ${ }^{8,9}$. In addition to the above two kinds of sunlight-driven catalysis, using sunlight-converted thermal energy to drive thermal catalysis, that is, solar-heating catalysis, has aroused much attention ${ }^{10,11}$. In solar-heating catalysis, the photothermal material is the key for diverse solar-heating applications ${ }^{12}$, and it is challenged by achieving a high solar-heating temperature upon irradiation by diluted ambient sunlight ${ }^{13-17}$. In previous reports ${ }^{18}$, coordinated regulation of high solar absorption ${ }^{19}$ and low thermal conductivity by materials such as black photothermal materials with porous $^{20}$, amorphous ${ }^{21}$, and layered structures ${ }^{22}$ was the main strategy used to improve solar-heating temperatures ${ }^{23,24}$. For example, a nanohybrid combining zeolitic imidazolate frameworks (ZIFs) and graphene was demonstrated to synergistically intensify sunlight absorbance ( $98 \%$ solar-to-thermal conversion efficiency) and thermal energy insulation capability (ultralow thermal conductivity of $\sim 0.2 \mathrm{~W} \mathrm{mK}^{-1}$ ) to achieve a reported maximum solar-heating temperature of $120^{\circ} \mathrm{C}$ under 1 sun illumination (equal to an energy density of $\left.1 \mathrm{~kW} \mathrm{~m}^{-2}\right)^{25}$, which is still too low to drive most thermocatalytic reactions. From the ideal artificial-energy-input-free catalysis design point of view, it is necessary to propose a concept to further improve the solarheating temperatures.

Hydrogen energy has been considered one of the foundations for future energy systems ${ }^{26-28}$. Owing to the storage limitations of hydrogen, such as high pressure, leakage, and extensive safety precautions, Olah proposed a methanol economy, as methanol can act as a hydrogen carrier in future hydrogen energy systems ${ }^{29}$, which has the merits of high hydrogen storage density $\left(99 \mathrm{~kg} \mathrm{~m}^{-3}\right)$, high degree of safety, low cost and compatibility with existing fossil energy systems ${ }^{30-32}$. However, hydrogen generation from methanol and water by methanol steam reforming $\left(\mathrm{CH}_{3} \mathrm{OH}+\mathrm{H}_{2} \mathrm{O} \rightarrow \mathrm{CO}_{2}+3 \mathrm{H}_{2}\right.$, MSR $)$ requires a largescale external energy input $\left(16.47 \mathrm{~kJ} \text { energy for } 1 \mathrm{~mol} \text { of } \mathrm{H}_{2}\right)^{33}$. A large amount of energy consumption has become the bottleneck for the large-scale application of methanol-hydrogen energy systems. Using sunlight to drive MSR is an attractive way to solve the artificial energy consumption problem ${ }^{34-36}$. As far as we know, the state-of-the-art sunlight-driven hydrogen production rate from methanol and water is $\sim 46 \mathrm{mmol} \mathrm{g}^{-1} \mathrm{~h}^{-137-41}$, far behind industry requirements ${ }^{42,43}$. Therefore, development of an artificial-energy-input-free MSR mode with a greatly improved reaction rate is urgent for its applicability.

Herein, taking a typical narrow-band gap photothermal material, $\mathrm{Bi}_{2} \mathrm{Te}_{3}$, as an example, we demonstrate a concept to increase the sunlight irradiation temperature of photothermal materials in which a heterogeneous $\mathrm{Bi}_{2} \mathrm{Te}_{3}$ thin-film structure is synthesized on a $\mathrm{Cu}$ support $\left(\mathrm{Bi}_{2} \mathrm{Te}_{3} / \mathrm{Cu}\right)$ to simultaneously balance sunlight absorption and thermal radiation ${ }^{22,44}$. Sunlight absorption and thermal dissipation can be controlled by tuning the thickness of the $\mathrm{Bi}_{2} \mathrm{Te}_{3}$ thin film, resulting in a 1 sun heating temperature of $317^{\circ} \mathrm{C}$, which is much higher than that of pure $\mathrm{Bi}_{2} \mathrm{Te}_{3}\left(93^{\circ} \mathrm{C}\right)$. Moreover, this strategy can also generally raise the 1 sun-heating temperatures of other photothermal materials to above $250^{\circ} \mathrm{C}$, and a reaction device based on $\mathrm{Bi}_{2} \mathrm{Te}_{3} / \mathrm{Cu}$ can heat catalysts to $305^{\circ} \mathrm{C}$ under 1 sun irradiation. Furthermore, a soft templating method is developed to synthesize CuZnAl nanosheets, which have excellent thermocatalytic MSR activity and stability due to their ultrathin thickness, large specific surface area, and uniform elemental distribution. Consequently, without consuming artificial energy, $\mathrm{CuZnAl}$ nanosheets combined with the $\mathrm{Bi}_{2} \mathrm{Te}_{3} / \mathrm{Cu}$-based device exhibit a solar-heating MSR performance that is far beyond all of sunlight-driven methanol-based hydrogen production systems reported to date. Moreover, a scalable model is constructed in this work, and it successfully produces $23.27 \mathrm{~m}^{3} /$ day of hydrogen from MSR under $6 \mathrm{~m}^{2}$ of outdoor sunlight irradiation in the spring.

\section{Results}

Using $\mathrm{Bi}_{2} \mathrm{Te}_{3} / \mathrm{Cu}$ to achieve a high solar-heating temperature. $\mathrm{Bi}_{2} \mathrm{Te}_{3}$ is a typical photothermal material with a narrow band gap $(<0.2 \mathrm{eV})^{45,46}$ that can nearly fully absorb the solar spectrum (Supplementary Fig. 1a, b) and has a high carrier concentration of $0.84-1.11 \times 10^{19} \mathrm{~cm}^{-3}$ (Supplementary Fig. 1c). Therefore, absorbed sunlight can be fully thermalized by this type of narrowbandgap semiconductor via electron-phonon and electron-electron scattering ${ }^{47}$. For instance, Cheng et al. reported that $\mathrm{Bi}_{2} \mathrm{Te}_{3}$ could convert up to $99 \%$ of solar energy into heat energy ${ }^{48}$. To achieve a high solar irradiation temperature, besides the superior solar-tothermal conversion, it is also necessary to localize the sunlightconverted heat energy in $\mathrm{Bi}_{2} \mathrm{Te}_{3}$ to reduce the amount of heat dissipation. Although vacuum protection was applied to cut off the heat conduction loss of the pure $\mathrm{Bi}_{2} \mathrm{Te}_{3}$ film, the 1 -sun $\left(1 \mathrm{~kW} \mathrm{~m}{ }^{-2}\right)$ illumination temperature of the pure $\mathrm{Bi}_{2} \mathrm{Te}_{3}$ film was only $93^{\circ} \mathrm{C}$ (Supplementary Fig. 1d). As a blackbody material (Fig. 1a ${ }^{49}$, the heat dissipation of the pure $\mathrm{Bi}_{2} \mathrm{Te}_{3}$ film includes not only the heat conduction loss but also, importantly, the violent heat radiation loss caused by infrared light (IR) radiation (IR emissivity of 0.91 , as shown in the Supplementary Information $)^{50}$. Therefore, minimizing the IR radiation of $\mathrm{Bi}_{2} \mathrm{Te}_{3}$ is the key to increasing its solar irradiation temperature. The IR light irradiated by $\mathrm{Bi}_{2} \mathrm{Te}_{3}$ is produced by lattice vibrations, and the lattice vibrations are proportional to the number of atoms in $\mathrm{Bi}_{2} \mathrm{Te}_{3}{ }^{51}$. From the physical principle, reducing the number of atoms in the $\mathrm{Bi}_{2} \mathrm{Te}_{3}$ structure can weaken IR radiation, so our strategy involves synthesizing a $\mathrm{Bi}_{2} \mathrm{Te}_{3}$ thin film to minimize the number of atoms and minimize the IR radiation, as shown in Fig. 1b. To achieve a low-IR radiation of the $\mathrm{Bi}_{2} \mathrm{Te}_{3}$ thin-film structure, the supports used to deposit the $\mathrm{Bi}_{2} \mathrm{Te}_{3}$ thin film also need to exhibit the low-IR radiation property. However, the supports used to deposit $\mathrm{Bi}_{2} \mathrm{Te}_{3}$ thin films are usually silicon wafer, which is also a typical blackbody material with strong IR radiation capability and cannot be used as a support for reducing the IR radiation of the whole $\mathrm{Bi}_{2} \mathrm{Te}_{3}$ thin-film structure ${ }^{49}$. Unlike blackbody materials, the highly conductive metal $\mathrm{Cu}$ contains a large number of nearly free electrons that can prevent the spillover of IR light ${ }^{52}$, making $\mathrm{Cu}$ have near-zero IR radiation ( 3\% IR emissivity, Supplementary Fig. 2) ${ }^{53,54}$. Therefore, $\mathrm{Cu}$ film is selected as the support to synthesize $\mathrm{Bi}_{2} \mathrm{Te}_{3}$ thin films to make the hybrid have merits such as superior solar-to-thermal conversion from $\mathrm{Bi}_{2} \mathrm{Te}_{3}$ and low-IR radiation from $\mathrm{Cu}^{55}$. By controlling the deposition time, the thickness of the $\mathrm{Bi}_{2} \mathrm{Te}_{3}$ film on the $\mathrm{Cu}$ support was tuned to $3 \mu \mathrm{m}$ (Fig. 1c), $100 \mathrm{~nm}$ (Fig. 1d), and $15 \mathrm{~nm}$ (Fig. 1e). The interface structure is shown in Supplementary Fig. 3. When the thickness of the $\mathrm{Bi}_{2} \mathrm{Te}_{3}$ film in $\mathrm{Bi}_{2} \mathrm{Te}_{3} / \mathrm{Cu}$ was $3 \mu \mathrm{m}$, the 1 -sun irradiation temperature was $97^{\circ} \mathrm{C}$ with vacuum protection (Fig. 1f), $\sim 4{ }^{\circ} \mathrm{C}$ higher than that of pure $\mathrm{Bi}_{2} \mathrm{Te}_{3}\left(93^{\circ} \mathrm{C}\right.$, Supplementary Fig. 1d) under the same conditions. Surprisingly, as the thickness of the $\mathrm{Bi}_{2} \mathrm{Te}_{3}$ film in $\mathrm{Bi}_{2} \mathrm{Te}_{3} / \mathrm{Cu}$ was reduced to $100 \mathrm{~nm}$, the 1-sun irradiation temperature of vacuum-protected $\mathrm{Bi}_{2} \mathrm{Te}_{3} / \mathrm{Cu}$ increased sharply to $317^{\circ} \mathrm{C}$ (Fig. 1g), which was not only $224^{\circ} \mathrm{C}$ higher than that of pure $\mathrm{Bi}_{2} \mathrm{Te}_{3}$ but also $197^{\circ} \mathrm{C}$ higher than the reported highest 

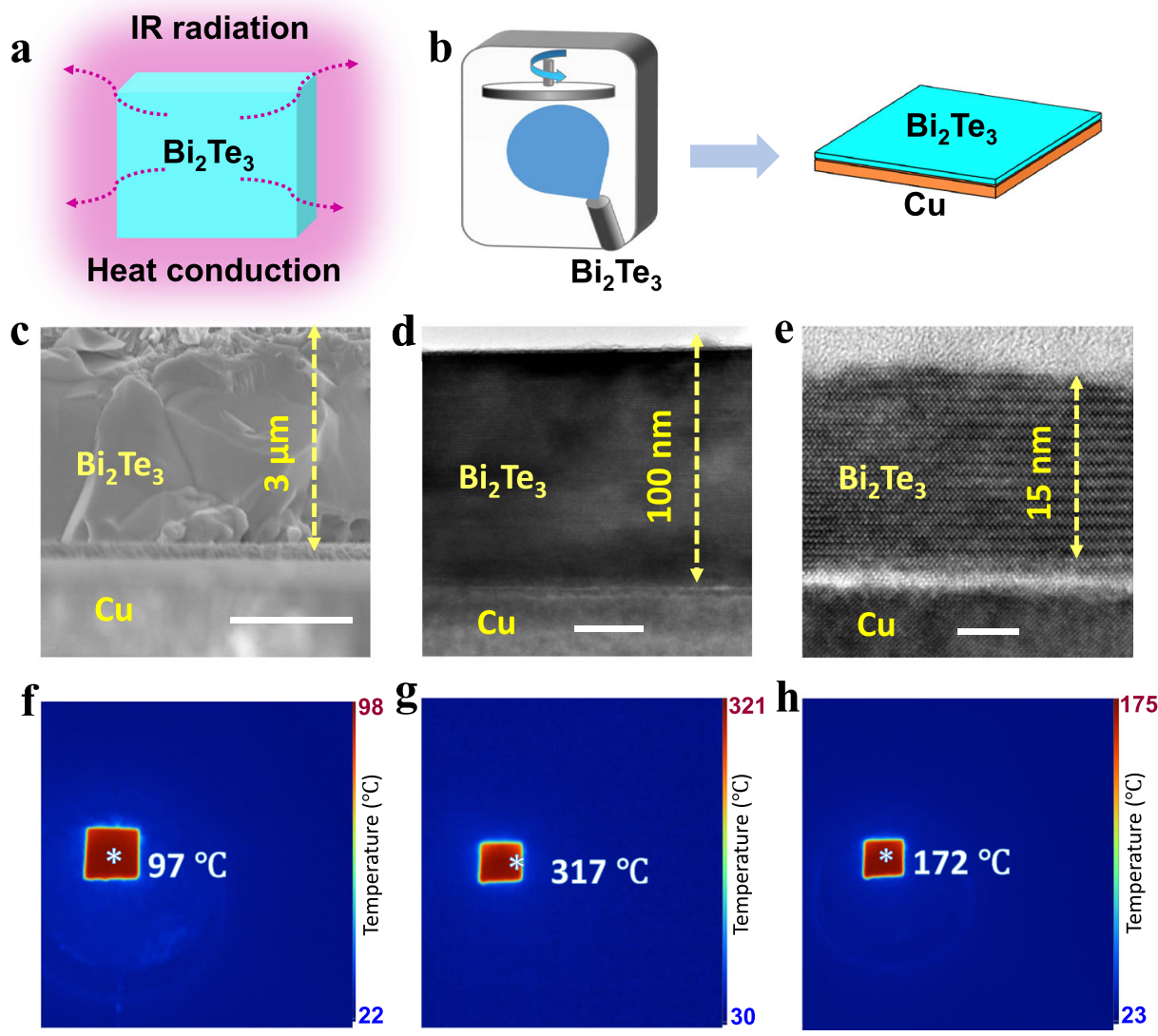

Fig. 1 Heterostructure strategy used to increase the solar irradiation temperature of $\mathbf{B i}_{\mathbf{2}} \mathbf{T e}_{\mathbf{3}}$. a Map of the heat dissipation of the pure $\mathrm{Bi}_{2} T e_{3}$ film. b Synthesis of the $\mathrm{Bi}_{2} \mathrm{Te}_{3}$ thin film on a Cu support $\left(\mathrm{Bi}_{2} \mathrm{Te}_{3} / \mathrm{Cu}\right.$ ). c-e SEM and TEM images of $\mathrm{Bi}_{2} \mathrm{Te}_{3} / \mathrm{Cu}$ with $3 \mu \mathrm{m}-, 100 \mathrm{~nm}-$, and $15 \mathrm{~nm}$-thick $\mathrm{Bi}_{2} T \mathrm{e}_{3}$. f-h IR images of vacuum-protected $\mathrm{Bi}_{2} \mathrm{Te}_{3} / \mathrm{Cu}$ with $3 \mu \mathrm{m}$-, $100 \mathrm{~nm}$-, and $15 \mathrm{~nm}$-thick $\mathrm{Bi}_{2} \mathrm{Te}_{3} . \mathrm{A} \mathrm{CaF}_{2}$ glass fully covered each sample, and the vacuum degree of this equipment was $1.0 \times 10^{-3} \mathrm{~Pa}$. The scale bars in $\mathbf{c}$, $\mathbf{d}$, and $\mathbf{e}$ are 1500,30 , and $5 \mathrm{~nm}$, respectively.

1-sun irradiation temperature of photothermal materials $\left(120^{\circ} \mathrm{C}\right)$, as far as we know ${ }^{25}$. This indicates that this strategy is useful for improving the solar-heating temperature of photothermal materials. Furthermore, when we reduced the thickness of $\mathrm{Bi}_{2} \mathrm{Te}_{3}$ in $\mathrm{Bi}_{2} \mathrm{Te}_{3} /$ $\mathrm{Cu}$ to $15 \mathrm{~nm}$ (Fig. 1e), the 1-sun irradiation temperature was only $172{ }^{\circ} \mathrm{C}$ (Fig. 1h), $145^{\circ} \mathrm{C}$ lower than that of $\mathrm{Bi}_{2} \mathrm{Te}_{3} / \mathrm{Cu}$ with a $\mathrm{Bi}_{2} \mathrm{Te}_{3}$ thickness of $100 \mathrm{~nm}$. Therefore, the thickness of $\mathrm{Bi}_{2} \mathrm{Te}_{3}$ has an important influence on the sunlight irradiation temperature of $\mathrm{Bi}_{2} \mathrm{Te}_{3} / \mathrm{Cu}$.

Thickness effect of $\mathrm{Bi}_{2} \mathrm{Te}_{3}$ and the device based on $\mathrm{Bi}_{2} \mathrm{Te}_{3} / \mathrm{Cu}$. To explain the effect of $\mathrm{Bi}_{2} \mathrm{Te}_{3}$ thin-film thickness on the sunlight irradiation temperature of $\mathrm{Bi}_{2} \mathrm{Te}_{3} / \mathrm{Cu}$, we measured the light absorbed by the three $\mathrm{Bi}_{2} \mathrm{Te}_{3} / \mathrm{Cu}$ samples. For the $3 \mu \mathrm{m}-, 100 \mathrm{~nm}$-, and $15 \mathrm{~nm}$-thick $\mathrm{Bi}_{2} \mathrm{Te}_{3}$ thin films in $\mathrm{Bi}_{2} \mathrm{Te}_{3} / \mathrm{Cu}$, Fig. $2 \mathrm{a}-\mathrm{c}$ show absorbances in the sunlight region (400-2000 nm) of $~ 94 \%, 89 \%$, and $43 \%$, respectively. $\mathrm{Bi}_{2} \mathrm{Te}_{3}$ has a narrow bandgap of $<0.2 \mathrm{eV}^{45,46}$; thus, sunlight has enough energy to excite electron transitions in $\mathrm{Bi}_{2} \mathrm{Te}_{3}{ }^{56,57}$. And, the film thickness of $\mathrm{Bi}_{2} \mathrm{Te}_{3}$ must be $\geq 100 \mathrm{~nm}$ to ensure more than $89 \%$ solar spectrum absorption. However, the absorption in the IR region was 4 and $5 \%$ when the thickness of the $\mathrm{Bi}_{2} \mathrm{Te}_{3}$ thin film in $\mathrm{Bi}_{2} \mathrm{Te}_{3} / \mathrm{Cu}$ was 15 and $100 \mathrm{~nm}$, respectively (Fig. $2 \mathrm{~b}, \mathrm{c}$ ), and it increased to $60 \%$ when the thickness of the $\mathrm{Bi}_{2} \mathrm{Te}_{3}$ thin film was further increased to $3 \mu \mathrm{m}$ (Fig. 2a). As the absorptivity of light is equal to the emissivity of the corresponding light ${ }^{54}$, the $60 \%$ IR absorption showed that the IR emissivity of $\mathrm{Bi}_{2} \mathrm{Te}_{3} / \mathrm{Cu}$ with a $3 \mu$ m-thick $\mathrm{Bi}_{2} \mathrm{Te}_{3}$ thin film is $60 \%$, at least 10 times higher than that of $\mathrm{Bi}_{2} \mathrm{Te}_{3} / \mathrm{Cu}$ with $100 \mathrm{~nm}$
(5\%)- and $15 \mathrm{~nm}$ (4\%)-thick $\mathrm{Bi}_{2} \mathrm{Te}_{3}$ thin films. For a more intuitive embodiment, we directly tested the IR radiation intensity (4-20 $\mu \mathrm{m})$ of these samples heated to $93^{\circ} \mathrm{C}$. As shown in Fig. $2 \mathrm{~d}$, $\mathrm{e}, \mathrm{f}$, the IR radiation intensities in the range of $4 \mu \mathrm{m}-20 \mu \mathrm{m}$ are $248 \mathrm{~W} \mathrm{~m}^{-2}, 20.7 \mathrm{~W} \mathrm{~m}^{-2}, 16.6 \mathrm{~W} \mathrm{~m}^{-2}$ for $\mathrm{Bi}_{2} \mathrm{Te}_{3} / \mathrm{Cu}$ with $3 \mu \mathrm{m}-$, $100 \mathrm{~nm}-$, and $15 \mathrm{~nm}$-thick $\mathrm{Bi}_{2} \mathrm{Te}_{3}$ thin films, respectively, significantly lower than the corresponding IR radiation of the pure $\mathrm{Bi}_{2} \mathrm{Te}_{3}$ film of $377 \mathrm{~W} \mathrm{~m}^{-2}$ (Supplementary Fig. 1e). Summarizing the solar absorptivity and IR emissivity listed in Supplementary Table 1 , the $100 \mathrm{~nm}$-thick $\mathrm{Bi}_{2} \mathrm{Te}_{3}$ layer can synergistically absorb $89 \%$ of sunlight and emit $5 \%$ of IR radiation; in other words, this $100 \mathrm{~nm}$-thick $\mathrm{Bi}_{2} \mathrm{Te}_{3}$ layer can absorb sunlight energy to the maximum extent and dissipate heat energy to the minimum extent so that the heat energy converted from sunlight is localized in the interior of the $\mathrm{Bi}_{2} \mathrm{Te}_{3}$ layer, resulting in a high sunlight irradiation temperature. This method is also suitable for other narrow-band gap semiconductors, such as $\mathrm{Ti}_{2} \mathrm{O}_{3}{ }^{58}, \mathrm{Cu}_{2} \mathrm{Se}^{59}$, and $\mathrm{Cu}_{2} \mathrm{~S}^{60}$. When we synthesized $\sim 200 \mathrm{~nm}$-thick $\mathrm{Ti}_{2} \mathrm{O}_{3}, \mathrm{Cu}_{2} \mathrm{Se}$, and $\mathrm{Cu}_{2} \mathrm{~S}$ on a $\mathrm{Cu}$ support (Supplementary Fig. 4), the $\mathrm{Ti}_{2} \mathrm{O}_{3} / \mathrm{Cu}$, $\mathrm{Cu}_{2} \mathrm{Se} / \mathrm{Cu}, \mathrm{Cu}_{2} \mathrm{~S} / \mathrm{Cu}$ heterostructures showed 1-sun irradiation temperatures of 295,271 , and $248^{\circ} \mathrm{C}$ (Fig. $2 \mathrm{~g}-\mathrm{i}$ ), respectively, obviously higher than the 1-sun heating temperatures of pure $\mathrm{Ti}_{2} \mathrm{O}_{3}\left(82^{\circ} \mathrm{C}\right), \mathrm{Cu}_{2} \mathrm{Se}\left(79^{\circ} \mathrm{C}\right)$, and $\mathrm{Cu}_{2} \mathrm{~S}\left(75^{\circ} \mathrm{C}\right)$, as shown in Supplementary Fig. 5. Meanwhile, different thicknesses of $\mathrm{Ti}_{2} \mathrm{O}_{3}$, $\mathrm{Cu}_{2} \mathrm{Se}$, and $\mathrm{Cu}_{2} \mathrm{~S}$ on the $\mathrm{Cu}$ support were synthesized (Supplementary Fig. 6), and the corresponding IR images (Supplementary Fig. 7) showed that the temperatures of those samples were all higher than the 1-sun heating temperatures of pure $\mathrm{Ti}_{2} \mathrm{O}_{3}$ $\left(82^{\circ} \mathrm{C}\right), \quad \mathrm{Cu}_{2} \mathrm{Se}\left(79^{\circ} \mathrm{C}\right)$, and $\mathrm{Cu}_{2} \mathrm{~S}\left(75^{\circ} \mathrm{C}\right)$, as shown in 

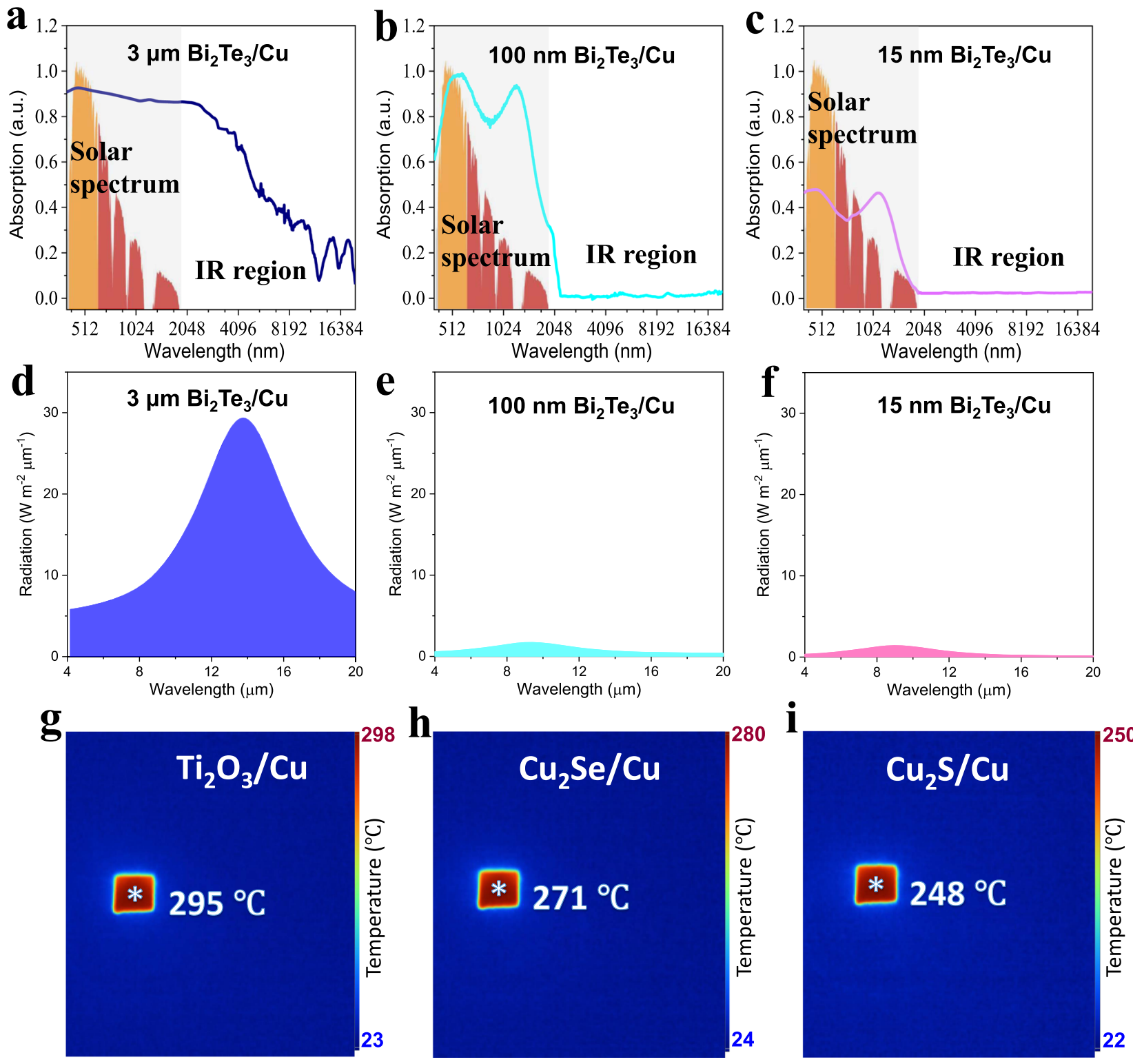

Fig. 2 Thickness effect and universality of the heterostructure strategy. a-c Normalized light absorption spectra of $\mathrm{Bi}_{2} \mathrm{Te}_{3} / \mathrm{Cu}_{\mathrm{with}} 3 \mu \mathrm{m}-, 100 \mathrm{~nm}-$, and $15 \mathrm{~nm}$-thick $\mathrm{Bi}_{2} \mathrm{Te}_{3}$ layers. d-f IR radiation ranging from $4 \mu \mathrm{m}$ to $20 \mu \mathrm{m}$ for $\mathrm{Bi}_{2} \mathrm{Te}_{3} / \mathrm{Cu}$ with $3 \mu \mathrm{m}$-, $100 \mathrm{~nm}$-, and $15 \mathrm{~nm}$-thick $\mathrm{Bi}_{2} \mathrm{Te}_{3}$ layers at $93^{\circ} \mathrm{C}$. $\mathbf{g}$-i IR images of vacuum-protected $\mathrm{Ti}_{2} \mathrm{O}_{3} / \mathrm{Cu}_{1} \mathrm{Cu}_{2} \mathrm{Se} / \mathrm{Cu}_{1} \mathrm{Cu}_{2} \mathrm{~S} / \mathrm{Cu}$ heterostructures. $\mathrm{A} \mathrm{CaF}{ }_{2}$ glass fully covered each sample, and the vacuum degree of this equipment was $1.0 \times 10^{-3} \mathrm{~Pa}$.

Supplementary Fig. 5. These results confirm that the proper thickness is significant for narrow-bandgap semiconductors to have weak IR radiation while maintaining enough solar spectral absorption to achieve a high temperature in the device.

As shown in Fig. 3a, hybridization of the $\mathrm{Cu}$ layer, $\mathrm{Bi}_{2} \mathrm{Te}_{3}$ layer, vacuum layer, and glass layer was successively achieved on the outer surface of the reaction tube to form a device (named the $\mathrm{Bi}_{2} \mathrm{Te}_{3} / \mathrm{Cu}$-based device). An optical image of a reaction tube is shown in Fig. 3b (Supplementary Fig. 8). Under 1-sun irradiation, the IR image shows that the inner temperature of the $\mathrm{Bi}_{2} \mathrm{Te}_{3} / \mathrm{Cu}$ based device was as high as $307^{\circ} \mathrm{C}$ (Fig. 3c). As we loaded the CuZnAl catalyst in the $\mathrm{Bi}_{2} \mathrm{Te}_{3} / \mathrm{Cu}$-based device, Fig. 3d shows that the temperature of the CuZnAl catalyst was higher than $200{ }^{\circ} \mathrm{C}$ at 0.5 -sun irradiation, and the temperature reached $305^{\circ} \mathrm{C}$ under 1-sun irradiation. The temperature of the $\mathrm{CuZnAl}$ catalystloaded $\mathrm{Bi}_{2} \mathrm{Te}_{3} / \mathrm{Cu}$-based device was $230^{\circ} \mathrm{C}$ higher than that of the $\mathrm{CuZnAl}$ catalyst directly irradiated by 1 sun (Supplementary Fig. 9).
Synthesis and characterization of the MSR catalyst: CuZnAl nanosheets. With the device that can generate a high solarheating temperature, we added commercial $\mathrm{CuZnAl}(\mathrm{C}-\mathrm{CuZnAl}$, Supplementary Fig. 10) to the $\mathrm{Bi}_{2} \mathrm{Te}_{3} / \mathrm{Cu}$-based device to test the sunlight-driven MSR performance. As shown in Supplementary Fig. 11, the 1 sun-driven MSR $\mathrm{H}_{2}$ generation rate achieved with C-CuZnAl was $79.3 \mathrm{mmol} \mathrm{g}^{-1} \mathrm{~h}^{-1}$, which is much higher than the reported record photocatalytic MSR value $\left(46.6 \mathrm{mmol} \mathrm{g}^{-1} \mathrm{~h}^{-1}\right)^{39}$, thus highlighting the importance of the $\mathrm{Bi}_{2} \mathrm{Te}_{3} / \mathrm{Cu}$-based device. To achieve better sunlight-driven MSR performance, more efficient catalysts for MSR need to be developed. In this work, polyvinylpyrrolidone (PVP, K30) was selected as a surfactant to synthesize this type of $\mathrm{CuZnAl}$ catalyst ${ }^{61}$. PVP was mixed with the $\mathrm{CuZnAl}$ precursor as a homogeneous solution, and then, the $\mathrm{Na}_{2} \mathrm{CO}_{3}$ solution was dropped to precipitate $\mathrm{CuZnAl}$ oxides (Fig. 4a). In the precipitation process, PVP was able to guide anisotropic growth and prevent aggregation. Consequently, we successfully controlled the morphology of CuZnAl oxides by 

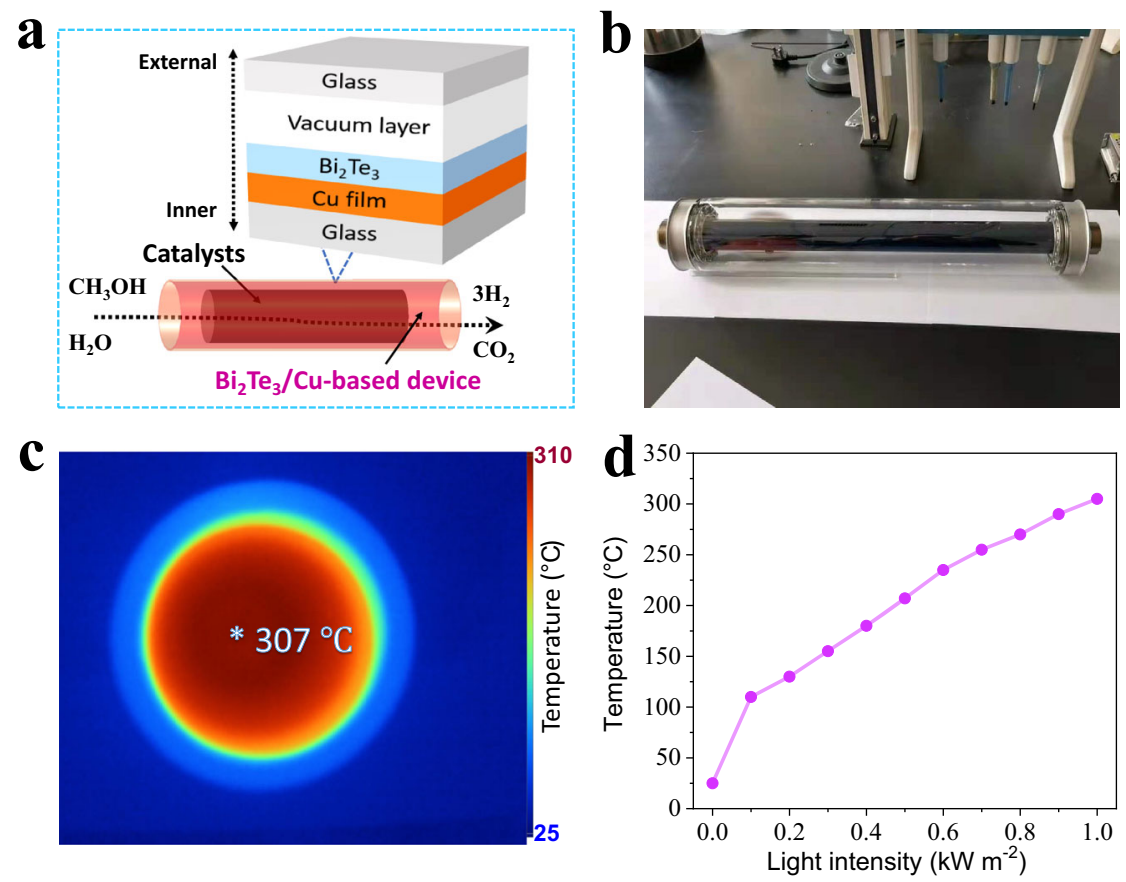

Fig. $3 \mathbf{B i}_{\mathbf{2}} \mathbf{T e}_{3} / \mathbf{C u}$-based device. a Map of the $\mathrm{Bi}_{2} \mathrm{Te}_{3} / \mathrm{Cu}$-based device loaded with catalysts for solar-heating MSR. $\mathbf{b}$ Photograph of the homemade $\mathrm{Bi} 2 \mathrm{Te}_{3} /$ Cu-based device. c Cross-sectional IR image of the $\mathrm{Bi}_{2} \mathrm{Te}_{3} / \mathrm{Cu}$-based device under 1-sun irradiation. $\mathbf{d}$ Temperature of the CuZnAl catalyst loaded in the $\mathrm{Bi}_{2} \mathrm{Te}_{3} / \mathrm{Cu}$-based device under different intensities of solar irradiation.

tuning the PVP amount (Supplementary Fig. 12, the optimized mass ratio of the PVP/CuZnAl precursor was 8). Supplementary Figure 13 shows that our synthesized sample could fully fill a $40 \mathrm{~L}$ bottle, revealing its scalable preparation. TEM imaging exhibits the porous nanosheet morphology of this sample (Fig. 4b), so we labeled the sample CuZnAl NS. The elemental mapping images in Fig. $4 \mathrm{c}$ reveal that $\mathrm{Cu}, \mathrm{Zn}$, and $\mathrm{Al}$ are homogeneously dispersed in the CuZnAl NS. Nanoparticles with diameters of $<5 \mathrm{~nm}$ were observed in the HRTEM image, with distinguishable lattice fringes assigned to $\mathrm{Cu}$ and $\mathrm{ZnO}$ (Fig. $4 \mathrm{~d}$ ). The small sizes of $\mathrm{Cu}$ and $\mathrm{ZnO}$ provided more interfaces, so they were generally recognized as highly active sites for MSR ${ }^{62}$. The thickness of the CuZnAl NS was measured to be $3.2 \mathrm{~nm}$ (Fig. 4e). According to the nitrogen adsorption-desorption measurements (Fig. 4f), the CuZnAl NS exhibited a large specific surface area of $195.2 \mathrm{~m}^{2} \mathrm{~g}^{-1}$, four times larger than that of commercial C-CuZnAl (Supplementary Fig. 10), ensuring a large number of active sites for catalytic reactions. As a result, the hydrogen production rate of $\mathrm{CuZnAl} N \mathrm{NS}$ was $1.02 \mathrm{~mol} \mathrm{~g}^{-1} \mathrm{~h}^{-1}$ at $260^{\circ} \mathrm{C}$, quintupling the $0.2 \mathrm{~mol} \mathrm{~g}^{-1} \mathrm{~h}^{-1}$ hydrogen production rate of $\mathrm{C}-\mathrm{CuZnAl}$ at $260^{\circ} \mathrm{C}$ (Fig. $4 \mathrm{~g}$ ), and the methanol conversion rate was 5.28\% (Supplementary Fig. 14). Additionally, we tested CuZnAl NS for 20 days, and the hydrogen production rate at $260^{\circ} \mathrm{C}$ was maintained at $\sim 1 \mathrm{~mol} \mathrm{~g}^{-1} \mathrm{~h}^{-1}$ (Supplementary Fig. 15), indicating the excellent stability of CuZnAl NS.

Solar-heating MSR. Ten grams of CuZnAl NS was placed in the $\mathrm{Bi}_{2} \mathrm{Te}_{3} / \mathrm{Cu}$-based device, and $0.0471 \mathrm{~m}^{2}$ of sunlight irradiation was the only energy source. When the sunlight density was higher than 0.5 sun, a clear hydrogen signal appeared for the CuZnAl NS loaded in the $\mathrm{Bi}_{2} \mathrm{Te}_{3} / \mathrm{Cu}$-based device, and the hydrogen generation rate increased to $3.1 \mathrm{~mol} \mathrm{~h}^{-1}$ (Fig. 5a) under 1 sun irradiation, corresponding to $310 \mathrm{mmolg}^{-1} \mathrm{~h}^{-1}$ and a methanol conversion rate of $45.34 \%$ (Supplementary Fig. 16). Meanwhile, the temperature of the CuZnAl NS loaded in the $\mathrm{Bi}_{2} \mathrm{Te}_{3} / \mathrm{Cu}$-based device during solar-heating MSR is shown in Supplementary
Fig. 17. Comparatively, MSR showed a hydrogen production rate of zero, as the CuZnAl NS were directly irradiated by 1-sun irradiation without the device (Fig. 5a). Since sunlight is the only energy source of the MSR catalytic reaction in solar-heating catalysis, as in the photocatalysis reaction, we listed the state-ofthe-art sunlight-driven hydrogen production rates in Fig. $5 \mathrm{~b}$ and Table 1 for comparison with our data. Figure $5 \mathrm{~b}$ and Table 1 confirm that our tested activity was at least 6 times the activity of the best sunlight-driven hydrogen production systems in the reported literature, e.g., $\mathrm{Ni} / \mathrm{CdS}\left(46.6 \mathrm{mmol} \mathrm{g}^{-1} \mathrm{~h}^{-1}\right)^{39}, \mathrm{NiS}_{\mathrm{x}} /$ $\mathrm{Cd}_{0.5} \mathrm{Zn}_{0.5} \mathrm{~S}\left(44.6 \mathrm{mmol} \mathrm{g}{ }^{-1} \mathrm{~h}^{-1}\right)^{34}$, Mg-black $\mathrm{TiO}_{2}(43.1 \mathrm{mmol}$ $\left.\mathrm{g}^{-1} \mathrm{~h}^{-1}\right)^{37}, \mathrm{Ni}(\mathrm{II}) / \mathrm{CdS}\left(43 \mathrm{mmol} \mathrm{g}^{-1} \mathrm{~h}^{-1}\right)^{63}, \mathrm{NiO} / \mathrm{LaNaTaO}_{3}$ (38.4 mmol g $\left.\mathrm{mm}^{-1} \mathrm{~h}^{-1}\right)^{64}, \mathrm{BP} / \mathrm{Bi}_{2} \mathrm{WO}_{6}\left(21.0 \mathrm{mmol} \mathrm{g}{ }^{-1} \mathrm{~h}^{-1}\right)^{65}, \mathrm{C}_{3} \mathrm{~N}_{4}$ $\left(19 \mathrm{mmol} \mathrm{g}^{-1} \mathrm{~h}^{-1}\right)^{66}, \mathrm{CdS} / 2 \mathrm{H}-\mathrm{MoS}_{2}\left(16.6 \mathrm{mmol} \mathrm{g}^{-1} \mathrm{~h}^{-1}\right)^{67}$, $\mathrm{N}$-doped black $\mathrm{TiO}_{2}\left(15 \mathrm{mmol} \mathrm{g}{ }^{-1} \mathrm{~h}^{-1}\right)^{68}, \mathrm{Sr} 2 \mathrm{MgSi} 2 \mathrm{O} 7: \mathrm{Eu}^{2+}$ $\left(14 \mathrm{mmol} \mathrm{g}^{-1} \mathrm{~h}^{-1}\right)^{69}$, and black $\mathrm{TiO}_{2} \quad\left(10 \mathrm{mmolg}^{-1} \mathrm{~h}^{-1}\right)^{36}$. Based on the experimental data, the solar-to-hydrogen (STH) conversion efficiencies of $\mathrm{CuZnAl} \mathrm{NS}$ in the $\mathrm{Bi}_{2} \mathrm{Te}_{3} / \mathrm{Cu}$-based device were calculated to be $31.9 \%$ and $30.1 \%$ under 0.9 - and 1 -sun irradiation, respectively (Fig. 5c). Note that the STH of our solar heating MSR is beyond the theoretical STH limit of photocatalytic MSR achieved through the route of photonphotogenerated electrons and holes-chemicals ${ }^{70}$. Ishii et al. reported that the average energy of photons in the solar spectrum is $\sim 1 \mathrm{eV}^{71}$. However, the reaction enthalpy of $\mathrm{MSR}$ is $0.086 \mathrm{eV}_{\text {per }}$ $\mathrm{H}\left(1 / 3 \mathrm{CH}_{3} \mathrm{OH}(\mathrm{l})+1 / 3 \mathrm{H}_{2} \mathrm{O}(\mathrm{l}) \rightarrow \mathrm{H}_{2}(\mathrm{~g})+1 / 3 \mathrm{CO}_{2}(\mathrm{~g})\right.$; detailed calculation shown in the Methods). Therefore, the STH ceiling of photocatalytic MSR under 1-sun illumination is $8.6 \%(0.086 \mathrm{eV} /$ $1 \mathrm{eV}$ ), equivalent to $\sim 1 / 3$ of the STH of our solar heating MSR system $(30.1 \%)$ under 1 -sun irradiation. This work reveals that solar heating catalysis via a solar-thermal energy-chemical route has an incomparable advantage over photocatalysis in reactions with a low energy barrier. Therefore, the $\mathrm{Bi}_{2} \mathrm{Te}_{3} / \mathrm{Cu}$-based device with $\mathrm{CuZnAl}$ NS opens a pathway for efficiently achieving solardriven hydrogen generation from methanol and water, in which solar heating is the only energy source used and has no energy 


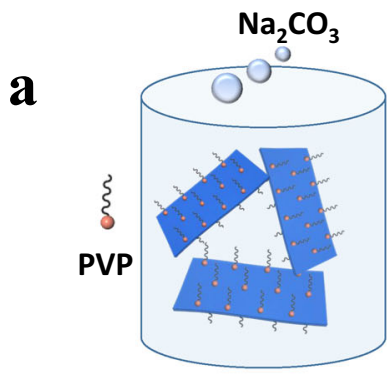

CuZnAl precursor

b

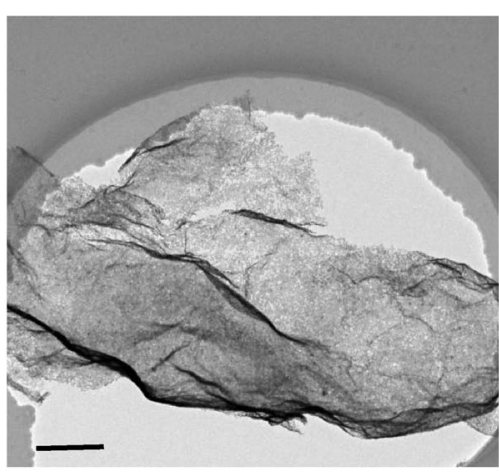

e

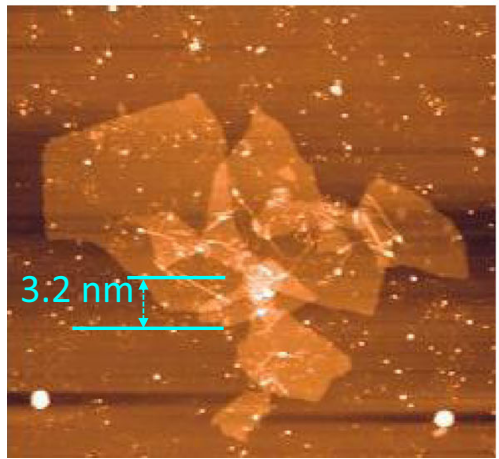

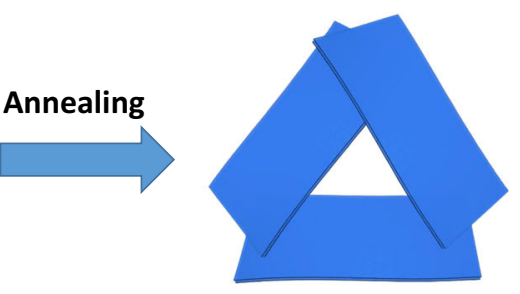

CuZnAl oxide nanosheets
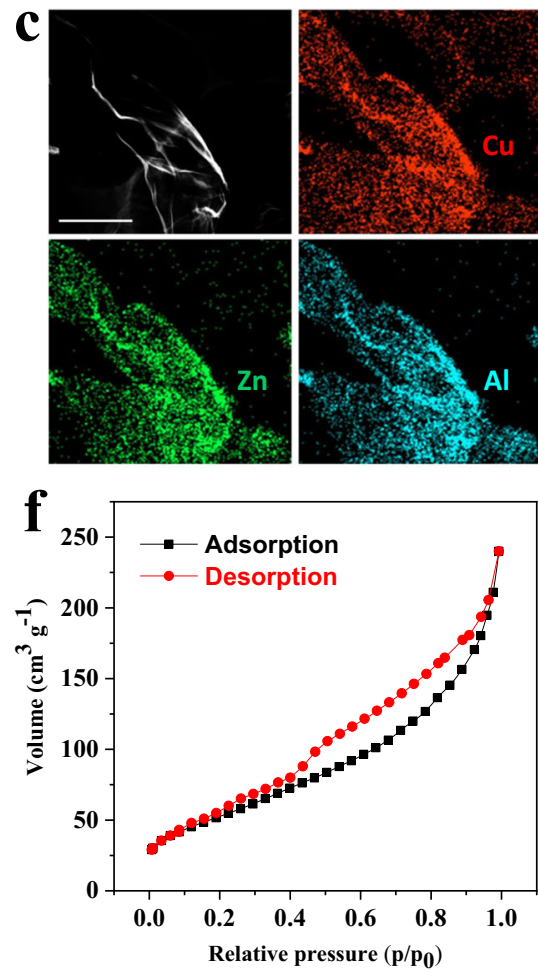

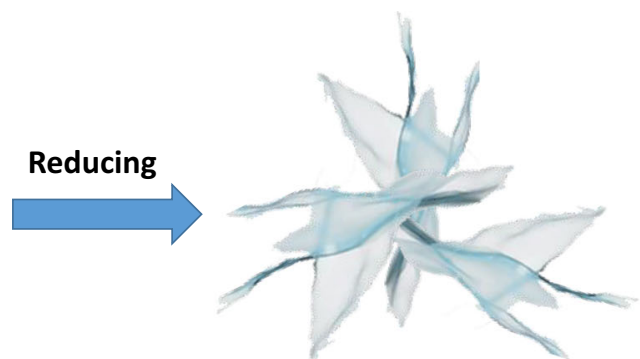

CuZnAI NS
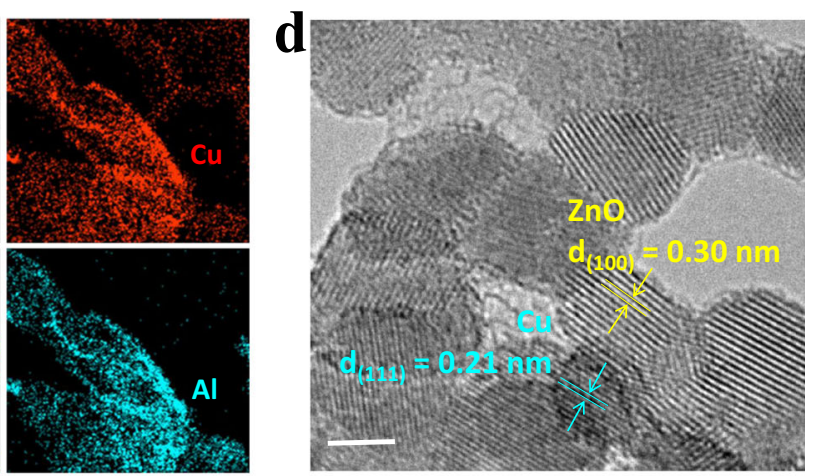

g

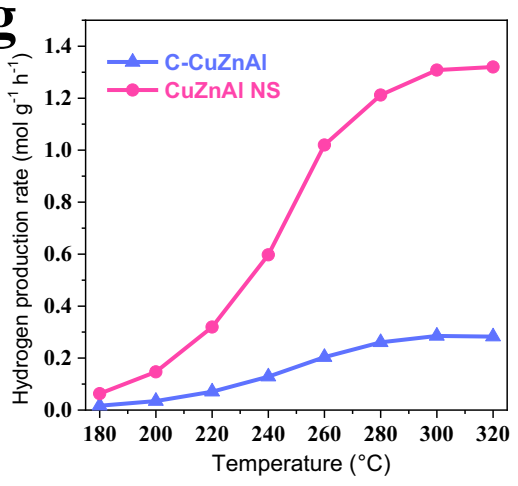

Fig. 4 Preparation and characterization of CuZnAI NS. a Schematic of the synthesis process for CuZnAI NS. TEM image b, elemental mapping image c, HRTEM image d, AFM image $\mathbf{e}$, and nitrogen adsorption and desorption isotherm $\mathbf{f}$ of CuZnAl NS. $\mathbf{g}$ Hydrogen production rate from the MSR of CuZnAl $\mathrm{NS}$ and $\mathrm{C}-\mathrm{CuZnAl}$ at different temperatures. Test conditions: $10 \mathrm{mg}$ of catalyst, $50 \mathrm{sccm}$ of $\mathrm{Ar}$, and $0.1 \mathrm{sccm}$ of methanol (the volume ratio of methanol to water $=1: 1.3$ ). The scale bars in $\mathbf{b}, \mathbf{c}$, and $\mathbf{d}$ are 200,500, and $2 \mathrm{~nm}$, respectively. CuZnAl NS and C-CuZnAl are abbreviations for CuZnAl nanosheets and commercial CuZnAl, respectively.

supply from artificial input is needed, meaning that artificial energy is not consumed. In addition to the high hydrogen production rate, the ratio of $\mathrm{CO}_{2}$ to $\mathrm{CO}_{2}+\mathrm{CO}$ in our solar-heating MSR strategy was higher than $99.2 \%$ under sunlight irradiation (Supplementary Fig. 18), indicating a low CO concentration in the hydrogen-producing process.

To test the capability of the $\mathrm{Bi}_{2} \mathrm{Te}_{3} / \mathrm{Cu}$-based device for largescale production (Supplementary Fig. 19), we prepared a scalable system, as shown in Fig. 5d. Its outdoor test was performed on 8 April 2021, with an ambient temperature of $6-21^{\circ} \mathrm{C}$ and a sunlight intensity of $0.15-0.52 \mathrm{~kW} \mathrm{~m}^{-2}$ (Fig. 5e) in the daytime in Baoding City of Hebei Province, China. To make the system work well in the morning and evening, the system was equipped with a parabolic reflector with a $6 \mathrm{~m}^{2}$ irradiation area to concentrate sunlight to moderate its solar-heating MSR ability (Supplementary Movie 1). As shown in Fig. 5f, MSR took place at 8:00 A.M. with a hydrogen production rate of $1.61 \mathrm{~m}^{3} \mathrm{~h}^{-1}$. After that, the rate rose sharply, and the hydrogen production rate reached a peak of $3.56 \mathrm{~m}^{3} \mathrm{~h}^{-1}$ at 12:00 P.M. and then gradually decreased to $1.19 \mathrm{~m}^{3} \mathrm{~h}^{-1}$ at 17:00 P.M. The total amount of hydrogen produced daily was up to $23.27 \mathrm{~m}^{3}$ under ambient sunlight irradiation, showing the potential of industrialization.

\section{Discussion}

In this work, we propose a solar-heating catalysis mode as a distinctive type of artificial-energy-input-free catalytic system. A heterostructure consisting of black photothermal materials, used to fully absorb sunlight, and a $\mathrm{Cu}$ support, used to weaken IR radiation, was used to increase the solar-heating temperature of photothermal materials. Taking $\mathrm{Bi}_{2} \mathrm{Te}_{3}$ as an example, we found that the solar-spectrum absorption and IR radiation of the $\mathrm{Bi}_{2} \mathrm{Te}_{3}$ film depended on the thickness of the $\mathrm{Bi}_{2} \mathrm{Te}_{3}$ film. Consequently, hybridization of the $100 \mathrm{~nm}$-thick $\mathrm{Bi}_{2} \mathrm{Te}_{3}$ film with a $\mathrm{Cu}$ support showed a 1 sun-heating temperature of $317^{\circ} \mathrm{C}$ with vacuum protection, $224^{\circ} \mathrm{C}$ higher than that of pure $\mathrm{Bi}_{2} \mathrm{Te}_{3}$ under the same conditions. This strategy is widely used in narrow-band gap materials, and the hybrids of $\mathrm{Ti}_{2} \mathrm{O}_{3} / \mathrm{Cu}, \mathrm{Cu}_{2} \mathrm{Se} / \mathrm{Cu}$, and $\mathrm{Cu}_{2} \mathrm{~S} / \mathrm{Cu}$ exhibited 1 sun-heating temperatures of 295,271 , and $248{ }^{\circ} \mathrm{C}$, respectively. A PVP-capped coprecipitation method was modified 

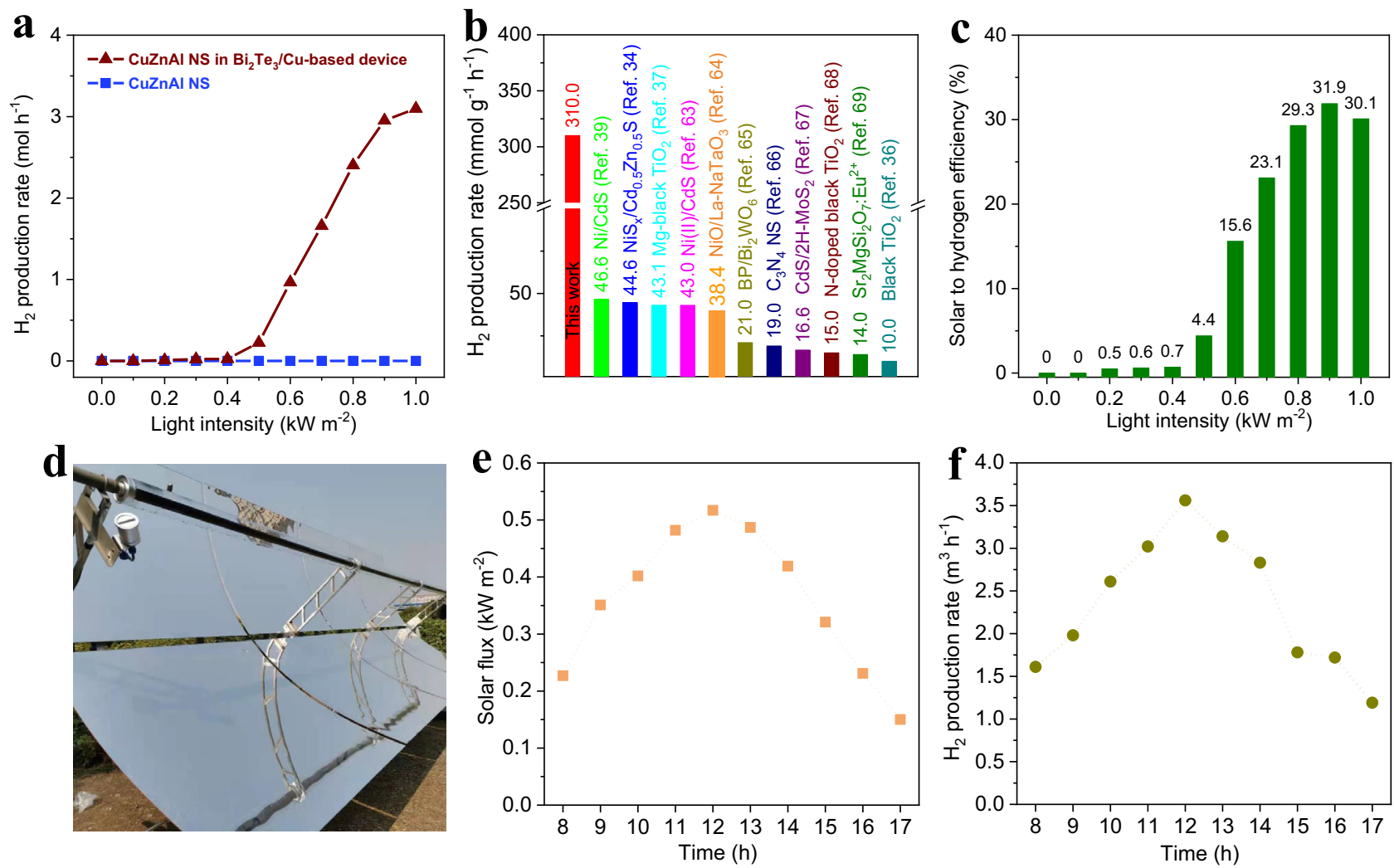

Fig. 5 Solar-heating MSR performance of $\mathbf{C u Z n A I ~ N S}$ with a $\mathbf{B i}_{\mathbf{2}} \mathbf{T} \mathbf{T e}_{\mathbf{3}} / \mathbf{C u}$-based device. a Hydrogen production rates from the MSR of CuZnAI NS loaded in the $\mathrm{Bi}_{2} \mathrm{Te}_{3} / \mathrm{Cu}$-based device and the device without $\mathrm{CuZnAI}$ NS under different sunlight irradiation. $\mathbf{b}$ Visual contrast diagram of the hydrogen production rates achieved under 1 sun illumination by the $\mathrm{Bi}_{2} \mathrm{Te}_{3} / \mathrm{Cu}$-based device loaded with CuZnAI NS and those of other photocatalysts. c STH efficiency of MSR achieved by the $\mathrm{Bi}_{2} \mathrm{Te}_{3} / \mathrm{Cu}$-based device loaded with $\mathrm{CuZnAl}$ NS under different intensities of solar irradiation. $\mathbf{d}$ Optical image of the solar-heating system used for hydrogen production from MSR under ambient sunlight irradiation. e Solar flux on April 08, 2021, in Baoding City, China. f MSR hydrogen production rate as a function of time under ambient sunlight irradiation. CuZnAl NS is the abbreviation for CuZnAl nanosheets.

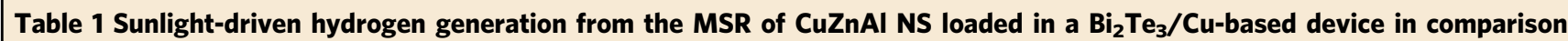
with the reported advanced sunlight-driven hydrogen generation systems.

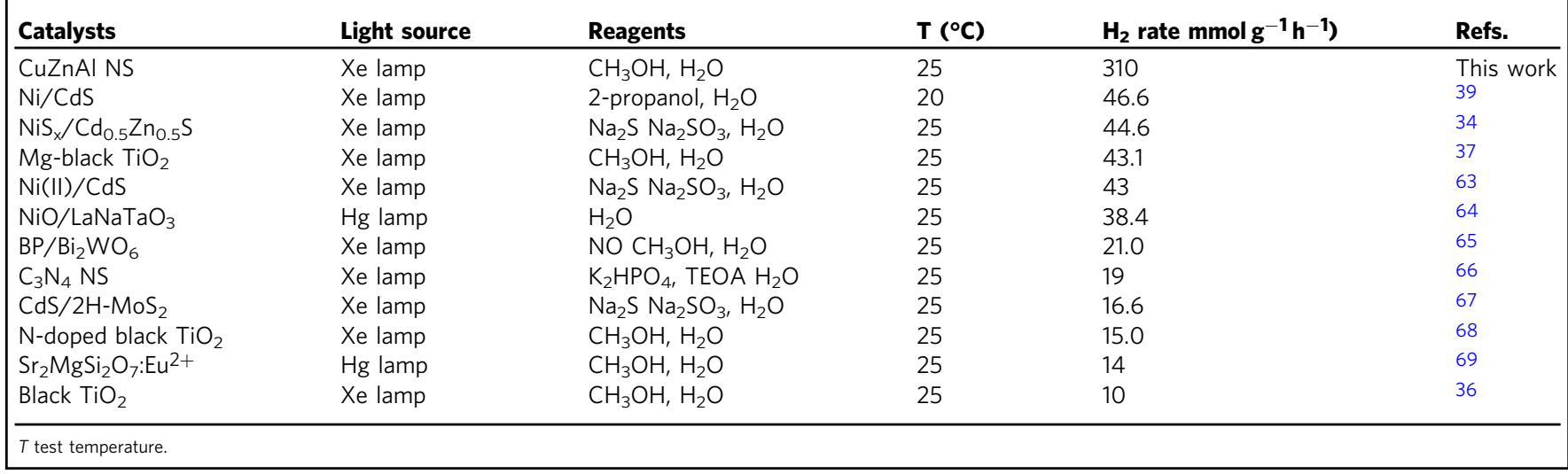

and used to synthesize CuZnAl nanosheets (CuZnAl NS) on a large scale with a thickness of $3.2 \mathrm{~nm}$, a larger specific surface area of $195.2 \mathrm{~m}^{2} \mathrm{~g}^{-1}$, and a $5-\mathrm{nm} \mathrm{Cu}$ nanoparticle as benchmark catalysts for MSR. Finally, based on $\mathrm{Bi}_{2} \mathrm{Te}_{3} / \mathrm{Cu}$, we synthesized a reaction device in which $\mathrm{CuZnAl}$ NS were heated to $305^{\circ} \mathrm{C}$ under 1-sun irradiation, and $0.15 \mathrm{~m}^{2}$ of 1 sun-heated MSR showed a hydrogen production rate of $3.1 \mathrm{~mol} \mathrm{~h}^{-1}$, at least 6 times higher than that reported for sunlight-driven hydrogen production systems, with an STH efficiency of $30.1 \%$ and 20 -day stability.
Moreover, an industrial demo of our system driven by $6 \mathrm{~m}^{2}$ of outdoor sunlight was able to generate $23.27 \mathrm{~m}^{3} /$ day of $\mathrm{H}_{2}$ from MSR. In these systems, the energy source used is only solar heating, and no other artificial energy is consumed.

\section{Methods}

Deposition of the $\mathrm{Bi}_{2} \mathbf{T e}_{3}$ film and synthesis of devices. SP-0707AS magnetron sputtering was used to deposit the $\mathrm{Bi}_{2} \mathrm{Te}_{3}$ film at a vacuum pressure lower than $7.0 \times 10^{-3} \mathrm{~Pa}$, and a 4 -axis rotation system was used to rotate the bases. $\mathrm{Bi}_{2} \mathrm{Te}_{3}$ and 
$\mathrm{Cu}$ were used as targets; the working gas was Ar with $99.99 \%$ purity. The bases used in Figs. $1-3$ and 5 were $\mathrm{Cu}$ films $20 \times 20 \times 0.1 \mathrm{~mm}$ in size, $\mathrm{Cu}$ films $20 \times 20 \times 0.1 \mathrm{~mm}$ in size, reaction tubes $250 \mathrm{~mm}$ in length and $30 \mathrm{~mm}$ in diameter, and stainless steel tubes $2000 \mathrm{~mm}$ in length and $42 \mathrm{~mm}$ in diameter, respectively. Before the deposition process, the bases were subsequently washed with deionized water, acetone, and ethanol.

(1) For the deposition of the $\mathrm{Bi}_{2} \mathrm{Te}_{3}$ film on the $\mathrm{Cu}$ film, glow discharge was applied to clean the $\mathrm{Cu}$ film, and then, the $\mathrm{Bi}_{2} \mathrm{Te}_{3}$ film was deposited. Finally, the sample was removed after passive cooling. The power was $5 \mathrm{~kW}$, the sputtering pressure was $9 \times 10^{-2} \mathrm{~Pa}$, the bias voltage was $150 \mathrm{~V}$, the sputtering temperature was $70^{\circ} \mathrm{C}$, and the sputtering times were $1 \mathrm{~min}$ and $6 \mathrm{~min}$ for $\mathrm{Bi}_{2} \mathrm{Te}_{3}$ films with $15 \mathrm{~nm}$ and $100 \mathrm{~nm}$ thicknesses, respectively. For the $3 \mu \mathrm{m}$-thick $\mathrm{Bi}_{2} \mathrm{Te}_{3}$ film, the sputtering pressure was $7 \times 10^{-1} \mathrm{~Pa}$, and the sputtering time was $15 \mathrm{~min}$.

(2) For the synthesis of the $\mathrm{Bi}_{2} \mathrm{Te}_{3} / \mathrm{Cu}$-based device involving the deposition of the $\mathrm{Cu}$ substrate and $\mathrm{Bi}_{2} \mathrm{Te}_{3}$ film on the reaction tube, glow discharge was first applied to clean the glass tube. Then, the $\mathrm{Cu}$ layer was deposited by the $\mathrm{Cu}$ target and the $\mathrm{Bi}_{2} \mathrm{Te}_{3}$ film was deposited by the $\mathrm{Bi}_{2} \mathrm{Te}_{3}$ target in an orderly manner, with the sample being removed after passive cooling. The power was $5 \mathrm{~kW}$, the sputtering pressure was $9 \times 10^{-2} \mathrm{~Pa}$, the bias voltage was $150 \mathrm{~V}$, the sputtering temperature was $70^{\circ} \mathrm{C}$, and the sputtering times for the $\mathrm{Cu}$ layer and $\mathrm{Bi}_{2} \mathrm{Te}_{3}$ film were $12 \mathrm{~min}$ and $6 \mathrm{~min}$, respectively. The thickness of the $\mathrm{Cu}$ layer was $\sim 10 \mu \mathrm{m}$. The followed antireflection film and glass vacuum layer were provided by Hebei Scientist Research Experimental and Equipment Trade Co., Ltd. with a $1 \times 10^{-3} \mathrm{~Pa}$ pressure. The final product is shown in Fig. $3 \mathrm{~b}$.

(3) For the synthesis of the device shown in Fig. 5d, involving the deposition of the $\mathrm{Cu}$ substrate and $\mathrm{Bi}_{2} \mathrm{Te}_{3}$ film on a stainless steel tube, glow discharge was first performed to clean stainless steel tube, and then, the $\mathrm{Cu}$ layer was deposited by the $\mathrm{Cu}$ target and the $\mathrm{Bi}_{2} \mathrm{Te}_{3}$ film was deposited by the $\mathrm{Bi}_{2} \mathrm{Te}_{3}$ target in an orderly manner. Finally, the sample was removed after passive cooling. The power was $5 \mathrm{~kW}$, the sputtering pressure was $9 \times 10^{-2} \mathrm{~Pa}$, the bias voltage was $150 \mathrm{~V}$, the sputtering temperature was $70^{\circ} \mathrm{C}$, and the sputtering times for the $\mathrm{Cu}$ layer and $\mathrm{Bi}_{2} \mathrm{Te}_{3}$ film were $12 \mathrm{~min}$ and $6 \mathrm{~min}$, respectively. The followed antireflection film and glass vacuum layer were provided by Hebei Scientist Research Experimental and Equipment Trade Co., Ltd. at a $1 \times 10^{-3} \mathrm{~Pa}$ pressure. The tubes were welded together to form a reaction tube $6 \mathrm{~m}$ in length for the outdoor test.

Chemicals for catalysts. Commercial copper nitrate $\left(\mathrm{Cu}\left(\mathrm{NO}_{3}\right)_{2}\right)$, zinc nitrate hydrate $\left(\mathrm{Zn}\left(\mathrm{NO}_{3}\right)_{2} \cdot 6 \mathrm{H}_{2} \mathrm{O}\right)$, aluminum nitrate hydrate $\left(\mathrm{Al}\left(\mathrm{NO}_{3}\right)_{3} \cdot 9 \mathrm{H}_{2} \mathrm{O}\right)$, polyvinylpyrrolidone (PVP, K30), sodium borate, and sodium carbonate were purchased from Sinopharm Co., Ltd. The chemicals were all used without any further treatment.

Catalyst preparation (CuZnAI NS, C-CuZnAl). A total of $375.7 \mathrm{~g}$ of $\mathrm{Cu}\left(\mathrm{NO}_{3}\right)_{2}$, $297.4 \mathrm{~g}$ of $\mathrm{Zn}\left(\mathrm{NO}_{3}\right)_{2} \cdot 6 \mathrm{H}_{2} \mathrm{O}$, and $125.1 \mathrm{~g}$ of $\mathrm{Al}\left(\mathrm{NO}_{3}\right)_{3} \cdot 9 \mathrm{H}_{2} \mathrm{O}$ were dissolved in $20 \mathrm{~L}$ of deionized water (containing $760 \mathrm{~g}$ of sodium borate). Then, $32 \mathrm{~L}$ of $150 \mathrm{mg} \mathrm{mL}^{-1}$ PVP aqueous solution was added to the above solution. The mixture solution was denoted solution $\mathrm{A}$. Then, $0.2 \mathrm{M}$ aqueous $\mathrm{Na}_{2} \mathrm{CO}_{3}(10 \mathrm{~L})$ was prepared and denoted solution B. Solution B was slowly added to solution A under stirring at $65^{\circ} \mathrm{C}$. The mixture solution was further stirred for $1 \mathrm{~h}$ and aged for $16 \mathrm{~h}$ at $65^{\circ} \mathrm{C}$. The precipitate was collected by centrifugation, washed with water three times, and dried by freeze-drying. Then, CuZnAl NS were obtained by calcination at $400{ }^{\circ} \mathrm{C}$ in air for $6 \mathrm{~h}$ and reduced in $10 \% \mathrm{H}_{2} / \mathrm{Ar}$ at $300^{\circ} \mathrm{C}$ for $10 \mathrm{~h}$.

$\mathrm{C}-\mathrm{CuZnAl}$ was prepared by the coprecipitation method. Typically, $37.512 \mathrm{~g}$ of $\mathrm{Cu}\left(\mathrm{NO}_{3}\right)_{2}, 29.749 \mathrm{~g}$ of $\mathrm{Zn}\left(\mathrm{NO}_{3}\right)_{2} 6 \mathrm{H}_{2} \mathrm{O}$, and $12.504 \mathrm{~g}$ of $\mathrm{Al}\left(\mathrm{NO}_{3}\right)_{3} 9 \mathrm{H}_{2} \mathrm{O}$ were dissolved in $200 \mathrm{~mL}$ of deionized water. After stirring for $1 \mathrm{~h}$, the resulting solution and $\mathrm{Na}_{2} \mathrm{CO}_{3}$ aqueous solution $(0.2 \mathrm{M} ; 1 \mathrm{~L})$ were added dropwise and stirred at $65^{\circ} \mathrm{C}$ for $1 \mathrm{~h}$. After holding at $65^{\circ} \mathrm{C}$ for $4 \mathrm{~h}$ and ageing for $7 \mathrm{~h}$, the resulting precipitate was washed several times with deionized water and then fast-frozen in liquid nitrogen. The frozen cube was freeze-dried at $-55^{\circ} \mathrm{C}$ and then calcinated in air at $400{ }^{\circ} \mathrm{C}$ for $6 \mathrm{~h}$ to obtain $\mathrm{Cu}-\mathrm{Zn}$-Al-based oxides. Finally, the products were reduced to $10 \% \mathrm{H}_{2} / \mathrm{Ar}$ at $300^{\circ} \mathrm{C}$ for $10 \mathrm{~h}$ and named $\mathrm{C}$-CuZnAl.

We tested the density of both CuZnAl NS and C-CuZnAl. The density of the CuZnAl NS powder was $\sim 0.12 \mathrm{~g} \mathrm{~cm}^{-3}$, and that of the $\mathrm{C}-\mathrm{CuZnAl}$ powder was $\sim 0.795 \mathrm{~g} \mathrm{~cm}^{-3}$.

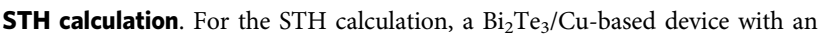
irradiation area of $0.0471 \mathrm{~m}^{2}$ was used in this experiment, and $10 \mathrm{~g}$ of $\mathrm{CuZnAl} \mathrm{NS}$ fully filled the inner space of this device. In this test, methanol and water were mixed as a solution with a methanol to water volume ratio $=1: 1.6$, and the mixed solution was then pumped into the system. To analyse the hydrogen gas product, we first removed $\mathrm{CO}_{2}$ from the produced gas through a $\mathrm{NaOH}$ solution $(5 \mathrm{M})$, and a flowmeter (MV-192-H2, Bronkhorst) was used to measure the flow rate, which was recognized as the rate of hydrogen production.

The STH efficiency of hydrogen generation from MSR was calculated as follows:

$$
\mathrm{STH}=(\Delta H \times \varepsilon / 24.5) /(I \times S \times 3600)
$$

The enthalpy change energies of methanol, $\mathrm{CO}_{2}, \mathrm{H}_{2}$, and $\mathrm{H}_{2} \mathrm{O}$ were -201.083 , $-393.505,0$, and $-241.818 \mathrm{~kJ} \mathrm{~mol}^{-1}$, respectively.
$\Delta \mathrm{H}$ is the reaction enthalpy change of methanol dehydrogenation $\left(1 / 3 \mathrm{CH}_{3} \mathrm{OH}\right.$ $\left.(\mathrm{l})+1 / 3 \mathrm{H}_{2} \mathrm{O}(\mathrm{l}) \rightarrow \mathrm{H}_{2}(\mathrm{~g})+1 / 3 \mathrm{CO}_{2}(\mathrm{~g}), \Delta \mathrm{H}=16.47 \mathrm{KJ} \mathrm{mol}^{-1}\right), \varepsilon(\mathrm{L})$ is the amount of $\mathrm{H}_{2}$ generated per hour detected by a flowmeter (MV-192-H2), $I$ is the light intensity $\left(\mathrm{kW} \mathrm{m}^{-2}\right)$, and $S$ is the irradiated area of catalysts $\left(0.0471 \mathrm{~m}^{-2}\right)$. The calculation details and data are shown in Supplementary Fig. 20.

As $1 \mathrm{eV}=1.6 \times 10^{-19} \mathrm{~J}$, the $\Delta \mathrm{H}$ per $\mathrm{H}_{2}$ was calculated to be $16.47 \mathrm{KJ} /$

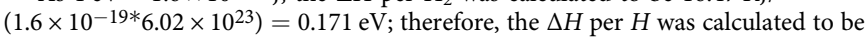
$0.171 \mathrm{eV} / 2=0.086 \mathrm{eV}$

\section{Data availability}

The data that support the findings of this study are available from the corresponding authors upon reasonable request.

Received: 15 July 2021; Accepted: 4 January 2022;

Published online: 09 February 2022

\section{References}

1. Salvatore, D. A. et al. Designing anion exchange membranes for $\mathrm{CO}_{2}$ electrolysers. Nat. Energy 6, 339-348 (2021).

2. Molloy, J. J. et al. Boron-enabled geometric isomerization of alkenes via selective energy-transfer catalysis. Science 369, 302-306 (2020).

3. Ma, J. J. et al. Photochemical intermolecular dearomative cycloaddition of bicyclic azaarenes with alkenes. Science 371, 1338-1345 (2021).

4. Kusaka, R., Nihonyanagi, S. \& Tahara, T. The photochemical reaction of phenol becomes ultrafast at the air-water interface. Nat. Chem. 13, 306-311 (2021).

5. Cho, H.-H. et al. A semiconducting polymer bulk heterojunction photoanode for solar water oxidation. Nat. Catal. 4, 431-438 (2021).

6. Zhang, W. et al. Hot-electron-induced photothermal catalysis for energydependent molecular oxygen activation. Angew. Chem. Int. Ed. 60, 4872-4878 (2021)

7. Wu, Z. et al. Niobium and titanium carbides (MXenes) as superior photothermal supports for $\mathrm{CO}_{2}$ photocatalysis. ACS Nano 15, 5696-5705 (2021).

8. Riente, P., Fianchini, M., Llanes, P., Pericàs, M. A. \& Noël, T. Shedding light on the nature of the catalytically active species in photocatalytic reactions using $\mathrm{Bi}_{2} \mathrm{O}_{3}$ semiconductor. Nat. Commun. 12, 625 (2021).

9. Zhao, B. et al. Photocatalysis-mediated drug-free sustainable cancer therapy using nanocatalyst. Nat. Commun. 12, 1345 (2021).

10. Kettler, J. et al. Inducing micromechanical motion by optical excitation of a single quantum dot. Nat. Nanotechnol. 16, 283-287 (2020).

11. Zhang, X. Y. et al. Electronic quality factor for thermoelectrics. Sci. Adv. 6, 5 (2020).

12. Baffou, G., Cichos, F. \& Quidant, R. Applications and challenges of thermoplasmonics. Nat. Mater. 19, 946-958 (2020).

13. Li, Y. G. et al. Selective light absorber-assisted single nickel atom catalysts for ambient sunlight-driven $\mathrm{CO}_{2}$ methanation. Nat. Commun. 10, 9 (2019).

14. Lou, Z. R. et al. $\mathrm{Fe}_{3} \mathrm{Si}$ assisted $\mathrm{Co}_{3} \mathrm{O}_{4}$ nanorods: a case study of photothermal catalytic CO oxidation under ambient solar irradiation. Nano Energy 62, 653-659 (2019).

15. Pei, J. et al. Development of integrated two-stage thermoelectric generators for large temperature difference. Sci. China-Technol. Sci. 62, 1596-1604 (2019).

16. Zhao, L. D., Zhang, B. P., Li, J. F., Zhou, M. \& Liu, W. S. Preparation and properties of Nano-SiC dispersed $\mathrm{Bi}_{2} \mathrm{Te}_{3}$ thermoelectric materials. Rare Met. Mater. Eng. 36, 408-411 (2007).

17. Xing, Y. F. et al. High-efficiency half-Heusler thermoelectric modules enabled by self-propagating synthesis and topologic structure optimization. Energy Environ. Sci. 12, 3390-3399 (2019).

18. Xie, B. Q. et al. Synergistic ultraviolet and visible light photo-activation enables intensified low-temperature methanol synthesis over copper/zinc oxide/alumina. Nat. Commun. 11, 11 (2020).

19. Li, Y. et al. Solution-processed all-ceramic plasmonic metamaterials for efficient solar-thermal conversion over 100-727 degrees. Adv. Mater. 33, 10 (2021).

20. Guo, Y. H. et al. Biomass-derived hybrid hydrogel evaporators for costeffective solar water purification. Adv. Mater. 32, 8 (2020).

21. Liu, G. G. et al. Elemental boron for efficient carbon dioxide reduction under light irradiation. Angew. Chem. Int. Ed. 56, 5570-5574 (2017).

22. $\mathrm{Xu}, \mathrm{Y}$. Q. et al. A general bimetal-ion adsorption strategy to prepare nickel single atom catalysts anchored on graphene for efficient oxygen evolution reaction. J. Energy Chem. 43, 52-57 (2020).

23. $\mathrm{Li}, \mathrm{Z}$. H. et al. Fe-based catalysts for the direct photohydrogenation of $\mathrm{CO}_{2}$ to value-added hydrocarbons. Adv. Energy Mater. 11, 9 (2021).

24. $\mathrm{Xi}, \mathrm{D}$. M. et al. NIR light-driving barrier-free group rotation in nanoparticles with an $88.3 \%$ photothermal conversion efficiency for photothermal therapy. Adv. Mater. 32, 8 (2020). 
25. Han, X. M. et al. Intensifying heat using MOF-isolated graphene for solardriven seawater desalination at $98 \%$ solar-to-thermal efficiency. Adv. Funct. Mater. 31, 7 (2021).

26. Takata, T. et al. Photocatalytic water splitting with a quantum efficiency of almost unity. Nature 581, 411-414 (2020).

27. Yuan, Y. \& Lei, A. Electrochemical oxidative cross-coupling with hydrogen evolution reactions. Acc. Chem. Res. 52, 3309-3324 (2019).

28. Chen, Y. et al. Engineering the atomic interface with single platinum atoms for enhanced photocatalytic hydrogen production. Angew. Chem. Int. Ed. 59, 1295-1301 (2020).

29. Olah, G. A. Beyond oil and gas: the methanol economy. Angew. Chem. Int. Ed. 44, 2636-2639 (2005).

30. Chen, G. et al. From solar energy to fuels: recent advances in light-driven C1 chemistry. Angew. Chem. Int. Ed. 58, 17528-17551 (2019).

31. Huang, Z. et al. Boron: its role in energy-related processes and applications. Angew. Chem. Int. Ed. 59, 8800-8816 (2020).

32. Song, J. et al. A review on fundamentals for designing oxygen evolution electrocatalysts. Chem. Soc. Rev. 49, 2196-2214 (2020).

33. Sá, S., Silva, H., Brandão, L., Sousa, J. M. \& Mendes, A. Catalysts for methanol steam reforming-a review. Appl. Catal. B Environ. 99, 43-57 (2010).

34. Liu, M. et al. Photocatalytic hydrogen production using twinned nanocrystals and an unanchored NiSx co-catalyst. Nat. Energy 1, 16151 (2016).

35. Fox, M. A. \& Dulay, M. T. Heterogeneous photocatalysis. Chem. Rev. 93, 341-357 (1993).

36. Chen, X., Liu, L., Yu, P. Y. \& Mao, S. S. Increasing solar absorption for photocatalysis with black hydrogenated titanium dioxide nanocrystals. Science 331, 746-750 (2011).

37. Sinhamahapatra, A., Jeon, J.-P. \& Yu, J.-S. A new approach to prepare highly active and stable black titania for visible light-assisted hydrogen production. Energy Environ. Sci. 8, 3539-3544 (2015).

38. Yu, X. et al. $\mathrm{Cu}_{2} \mathrm{ZnSnS}_{4}-\mathrm{Pt}$ and $\mathrm{Cu}_{2} \mathrm{ZnSnS}_{4}$-Au heterostructured nanoparticles for photocatalytic water splitting and pollutant degradation. J. Am. Chem. Soc. 136, 9236-9239 (2014)

39. Chai, Z. et al. Efficient visible light-driven splitting of alcohols into hydrogen and corresponding carbonyl compounds over a Ni-modified CdS photocatalyst. J. Am. Chem. Soc. 138, 10128-10131 (2016).

40. Nielsen, M. et al. Low-temperature aqueous-phase methanol dehydrogenation to hydrogen and carbon dioxide. Nature 495, 85-89 (2013).

41. Rodríguez-Lugo, R. E. et al. A homogeneous transition metal complex for clean hydrogen production from methanol-water mixtures. Nat. Chem. 5, 342-347 (2013).

42. Lin, K.-T., Lin, H., Yang, T. \& Jia, B. Structured graphene metamaterial selective absorbers for high efficiency and omnidirectional solar thermal energy conversion. Nat. Commun. 11, 1389 (2020).

43. Singh, S. C. et al. Solar-trackable super-wicking black metal panel for photothermal water sanitation. Nat. Sustainability 3, 938-946 (2020).

44. Netsou, A.-M. et al. Identifying native point defects in the topological insulator $\mathrm{Bi}_{2} \mathrm{Te}_{3}$. ACS Nano 14, 13172-13179 (2020).

45. Chen, Y. L. et al. Experimental realization of a three-dimensional topological insulator, $\mathrm{Bi}_{2} \mathrm{Te}_{3}$. Science 325, 178-181 (2009).

46. Dheepa, J., Sathyamoorthy, R. \& Subbarayan, A. Optical properties of thermally evaporated $\mathrm{Bi}_{2} \mathrm{Te}_{3}$ thin films. J. Cryst. Growth 274, 100-105 (2005).

47. Wang, J. et al. High-performance photothermal conversion of narrowbandgap $\mathrm{Ti}_{2} \mathrm{O}_{3}$ nanoparticles. Adv. Mater. 29, 1603730 (2017).

48. Wang, Z., Zhang, Z. M., Quan, X. \& Cheng, P. A perfect absorber design using a natural hyperbolic material for harvesting solar energy. Sol. Energy 159, 329-336 (2018).

49. $\mathrm{Li}, \mathrm{X}$. J. et al. $\mathrm{Bi}_{2} \mathrm{Te}_{3} / \mathrm{Si}$ thermophotovoltaic cells converting low-temperature radiation into electricity. Phys. Rev. Appl. 13, 041002 (2020).

50. Ni, G. et al. Steam generation under one sun enabled by a floating structure with thermal concentration. Nat. Energy 1, 16126 (2016).

51. Rice, A. M. et al. Photophysics modulation in photoswitchable metal-organic frameworks. Chem. Rev. 120, 8790-8813 (2020).

52. Ning, Y. P. et al. NiCrAlO/ $/ \mathrm{Al}_{2} \mathrm{O}_{3}$ solar selective coating prepared by direct current magnetron sputtering and water boiling. Sol. Energy Mater. Sol. Cell 219, 6 (2021).

53. Gong, S. et al. Preparation of ATO-incorporated composite latex with tailored structure and controllable size for highly spectrum-selective applications. Mater. Des. 180, 12 (2019).

54. Dao, T. D. et al. Infrared perfect absorbers fabricated by colloidal mask etching of $\mathrm{Al}-\mathrm{Al}_{2} \mathrm{O}_{3}-\mathrm{Al}$ trilayers. ACS Photon. 2, 964-970 (2015).

55. Zhang, J. et al. A flexible film to block solar radiation for daytime radiative cooling. Sol. Energy Mater. Sol. Cell 225, 12 (2021).

56. Lyu, Z. H., Chen, R. H., Mavrikakis, M. \& Xia, Y. N. Physical transformations of noble-metal nanocrystals upon thermal activation. Acc. Chem. Res. 54, 1-10 (2021).

57. Zhao, F., Guo, Y. H., Zhou, X. Y., Shi, W. \& Yu, G. H. Materials for solarpowered water evaporation. Nat. Rev. Mater. 5, 388-401 (2020).
58. Wang, J. et al. High-performance photothermal conversion of narrowbandgap $\mathrm{Ti}_{2} \mathrm{O}_{3}$ nanoparticles. Adv. Mater. 29, 6 (2017).

59. Nunna, R. et al. Ultrahigh thermoelectric performance in $\mathrm{Cu}_{2} \mathrm{Se}$-based hybrid materials with highly dispersed molecular CNTs. Energy Environ. Sci. 10, 1928-1935 (2017)

60. Peng, Q. K. et al. Boosting potassium storage performance of the Cu2S anode via morphology engineering and electrolyte chemistry. ACS Nano 14, 6024-6033 (2020)

61. Pati, S. et al. Catalytic $\mathrm{Pd}_{0.77} \mathrm{Ag}_{0.23}$ alloy membrane reactor for high temperature water-gas shift reaction: Methane suppression. Chem. Eng. J. 362, 116-125 (2019).

62. Luk, H. T., Mondelli, C., Ferré, D. C., Stewart, J. A. \& Pérez-Ramírez, J. Status and prospects in higher alcohols synthesis from syngas. Chem. Soc. Rev. 46, 1358-1426 (2017).

63. Zhao, G. et al. Superior photocatalytic $\mathrm{H}_{2}$ production with cocatalytic $\mathrm{Co} / \mathrm{Ni}$ species anchored on sulfide semiconductor. Adv. Mater. 29, 1703258 (2017).

64. Kato, H., Asakura, K. \& Kudo, A. Highly efficient water splitting into $\mathrm{H}_{2}$ and $\mathrm{O}_{2}$ over lanthanum-doped $\mathrm{NaTaO}_{3}$ photocatalysts with high crystallinity and surface nanostructure. J. Am. Chem. Soc. 125, 3082-3089 (2003).

65. $\mathrm{Hu}$, J. et al. Z-scheme $2 \mathrm{D} / 2 \mathrm{D}$ heterojunction of black phosphorus/monolayer $\mathrm{Bi}_{2} \mathrm{WO}_{6}$ nanosheets with enhanced photocatalytic activities. Angew. Chem. Int. Ed. 58, 2073-2077 (2019).

66. Liu, G. et al. Nature-inspired environmental "phosphorylation" boosts photocatalytic $\mathrm{H}_{2}$ production over carbon nitride nanosheets under visiblelight irradiation. Angew. Chem. Int. Ed. 54, 13561-13565 (2015).

67. Chang, K. et al. Targeted synthesis of 2H- and 1T-phase $\mathrm{MoS}_{2}$ monolayers for catalytic hydrogen evolution. Adv. Mater. 28, 10033-10041 (2016)

68. Lin, T. et al. Effective nonmetal incorporation in black titania with enhanced solar energy utilization. Energy Environ. Sci. 7, 967-972 (2014).

69. Cui, G. et al. Round-the-clock photocatalytic hydrogen production with high efficiency by a long-afterglow material. Angew. Chem. Int. Ed. 58, 1340-1344 (2019).

70. Nishiyama, H. et al. Photocatalytic solar hydrogen production from water on a $100 \mathrm{~m}^{2}$ scale. Nature 598, 304-307 (2021)

71. Ishii, T., Otani, K., Takashima, T. \& Xue, Y. Solar spectral influence on the performance of photovoltaic (PV) modules under fine weather and cloudy weather conditions. Prog. Photovolt. Res. Appl. 21, 481-489 (2013).

\section{Acknowledgements}

This work was supported by the Hebei Natural Science Foundation (Grant No. B2021201074), the Hebei Provincial Department of Science and Technology (Grant No. 216Z4303G), Hebei Education Department (Grant No. BJ2019016), the Advanced Talents Incubation Program of Hebei University (Grant Nos. 521000981248 and 8012605), the National Nature Science Foundation of China (Grant Nos. 51702078, 61774053, 61504036, 51972094, and 51971157), the Natural Science Foundation of Hebei Province (Grant Nos. B2021201034, F2019201446, and F2018201058), the National Key Research and Development Program of China (2018YFB1500503-02), the Scientific Research Foundation of Hebei Agricultural University (YJ201939), and the Tianjin Science Fund for Distinguished Young Scholars (19JCJQJC61800). Thank you for the TEM technical support provided by the Microanalysis Center, College of Physics Science and Technology, Hebei University.

\section{Author contributions}

Y.L., S.W. and J.L. conceived the project and contributed to the design of the experiments and analysis of the data. Y.L. and D.Y. prepared and characterized the $\mathrm{Bi}_{2} \mathrm{Te}_{3}$-based device. X.B., Bo.L. and F.Z. prepared and characterized the catalyst. Ba.L. and G.F. provided optical advice. X.S. conducted SEM and TEM. Y.L. and J.L. wrote the paper. All the authors discussed the results and commented on the manuscript.

\section{Competing interests}

The authors declare no competing interests.

\section{Additional information}

Supplementary information The online version contains supplementary material available at https://doi.org/10.1038/s41467-022-28364-y.

Correspondence and requests for materials should be addressed to Yaguang Li, Shufang Wang or Jun Luo.

Peer review information Nature Communications thanks Chang Liu and the other, anonymous, reviewers for their contribution to the peer review of this work. Peer reviewer reports are available.

Reprints and permission information is available at http://www.nature.com/reprints

Publisher's note Springer Nature remains neutral with regard to jurisdictional claims in published maps and institutional affiliations. 
(c) (i) Open Access This article is licensed under a Creative Commons Attribution 4.0 International License, which permits use, sharing, adaptation, distribution and reproduction in any medium or format, as long as you give appropriate credit to the original author(s) and the source, provide a link to the Creative Commons license, and indicate if changes were made. The images or other third party material in this article are included in the article's Creative Commons license, unless indicated otherwise in a credit line to the material. If material is not included in the article's Creative Commons license and your intended use is not permitted by statutory regulation or exceeds the permitted use, you will need to obtain permission directly from the copyright holder. To view a copy of this license, visit http://creativecommons.org/ licenses/by/4.0/.

(C) The Author(s) 2022 